\title{
Rebuilding the Maritime Culture of the Islands of Macaronesia: The Mythical and Historical Perception of Island Societies
}

\author{
Javier Luis Alvarez Santos \\ CHAM - Centre for the Humanities, NOVA FCSH (Faculty of \\ Social and Human Sciences, New University of Lisbon), Portugal \\ javier.santos@fcsh.unl.pt
}

Publication Information:

Received 30 October 2020, Accepted 24 November 2020, Available online 22 December 2020

DOI: 10.21463/jmic.2020.09.2.03

\begin{abstract}
While traditional historiography does establish that history cannot bypass islands, these spaces have in fact been regarded as anecdotes amidst the great historical processes and it has hardly been reflected upon the origin of its maritime culture. This research paper addresses a supranational territory, Macaronesia, and questions the origin of its island identity in order to understand what these islanders' perception of their plural maritime culture has been and how this identity was formed through myths and stories.

Methodologically, this research draws from a critique of transatlantic historiographic approaches while systematizing the main contributions of island historians. The study is underpinned by the analysis of accounts wherein chroniclers and historians allude to the origin of Macaronesic identity and culture. The islands are tackled on their own terms and the sociocultural perspective is emphasized with the aim of applying the fundamentals of nesology to historical knowledge. This research addresses the history, myth and historicality of the myth in order to understand the foundation of a contemporary aquapelagic and transnational society, whose early beginnings were marked by the complementarity between islands and the ability to transfer cultural traces between borders.
\end{abstract}

\section{Keywords}

Maritime culture, mythical perception, historical consciousness, conceptualisation of space, island societies 


\section{The Macaronesia: In search of a place in the studies of maritime culture}

Over the centuries, even before the Macaronesian islands became part of European knowledge, a myth had been established around island territories within the consciousness of the people of the Mediterranean (Aznar Vallejo, 2007: 175). With the passage of time, this construction - and the island which rests on it - has adapted to the different paradigms and hypotheses about the origin of the island world of the Atlantic. Without violating old arguments and the evolution of science, the islands have maintained their character of mythified space. There is, then, a link between the possible and the real, orthodoxy and science, between experience and the self-evident; between myth and history.

From the yet unfathomable sea, The Middle Ages had inherited from classical antiquity a series of values and ideas about this vast space which were somewhat confused and contradictory, far from any empirical interpretation. This appreciation was due, to a large extent, to its marginal situation in relation to the world known to the Europeans. These preconceptions were altered and reconfigured as the navigators entered within it (Babcock, 1922: 1). The Pillars of Hercules, the confines of the known world, grew farther and farther as the expeditions advanced south, with the frontier being located at each new land discovered.

This mitification of space has lingered in the memory of islanders to the present day. Even illustrous historians, born in insularity, such as the Americanist Francisco Morales Padrón, who explored this microcosm looking for a successful interpretation for the Atlantic islands through his insular status. In 1970 he published a short story called Siete islas para siete dioses (Seven Islands for Seven Gods) in which he reinterprets the island world and formulates the origin of the islands and their inhabitants through reconciling scientific discourse and the symbolic and mythical elements within this creationist theory of the islands. Expressions such as: "Around these principles revolve great theories", "subsequent research" or "oral tradition recounts", give the text the required scientific nature to prove the divine, classical and Atlantic origin of the Islands. Morales Padrón finally makes two seemingly antagonistic worlds, the fantastic and the earthly, the mythical and the historical, converge. With the arrival of the Europeans and the Christian faith, the benevolent insular gods and, with them, the blessed character of the islands disappeared. From then on, its original inhabitants "had to fight against human nature, against the earth to tease out its fruit and against the men of Europe, who, aware of the good weather, invaded the archipelago" (Morales Padrón, 1970: 12).

It was nevertheless Braudel, in his work La Méditerranée et le Monde Méditerranéen à l'Epoque de Philippe II (The Mediterranean and the Mediterranean world in the Age of Philip II), the first to give the islands their due place within strictly historical maritime dynamics. For this historian, island territories correspond to the nexus between different interconnected spaces (Braudel, 1976: 203). However, he states that the islands are dependent on the outside. Internal life must be precarious and conditioned by constant threats. Meanwhile, outside life is rich and located in the foreground of the historical situation. Its contribution "is of an amplitude that would not be expected from such miserable worlds"(Braudel, 1976: 203).

This importance of island spaces in a context as broad as that which the author refers to is conditioned by external agents. That is, it is the outsiders and the European economic system which add and give value to the islands. He argues that the imposition of a European economy - in the case of the islands of the "Atlantic Mediterranean", for example, sugarcane monoculture in Madeira and the Canary Islands during the first half of the 16th century - altered the island 
landscape and habits. In this context of the aggregation and dominance of mainland territories over island ones, global interest is superimposed over local interest, which can have serious consequences for the island society.

However, and as we have seen, from the development of Atlantic studies in the 1960s (Lucena Giraldo, 2010: 40), and especially regarding European expansion into this ocean, the islands began to be taken into consideration as a substantial element in transoceanic movements. According to Lucena Giraldo (2010:59), the historical construction of the identity of the Macaronesic Islands is largely based on the notions discussed at the time on the existence of a Hispanic Atlantic world, novelty and utopia, conflict and negotiation, of mestizaje and reinvention. Subsequently, adding to this interpretation of the oceanic world, Valladares Ramírez introduced political and ideological intentionality to the origin of its meaning. According to this author, the historiography of the second half of the twentieth century sought to justify the new international order which emerged following World War II, especially in the Atlantic area (Valladares Ramírez, 2012: 71), interpreting it as a traditionally interconnected and indivisible ocean. This space would have been built in a biased manner by and for Europeans.

In this construction of a historical entity (Outhwaite, 1957: 19), linked from Europe through a breeding ground of ports and stopovers, the islands were seen as a basic element for linking regions and, therefore, for the construction of this Atlantic space.

Such opportunity for the islands to bring different territories closer to the heart of the ocean was later called by Germán Santana Pérez and Juan Manuel Santana Pérez (2002) as "the blessed door". A door which is, sometimes, open, favouring fluid contacts, and which at other times remains closed, despite the closeness of the neighbourly behaviour at other times. From an unparalleled contextualization in insular historiography, these authors manage to build a global history from the particularity of the analysis of a microspace. It is a circumatlantic history that crosses national boundaries and classic space borders to focus on the consistent affinity of links between island regions and the domestic space represented by the Atlantic. According to the authors:

Studies on this continent (Africa) include some interesting Ancient Regime papers, almost always referring to a specific area. But there is a lack of research on the overall relationship of the Canary Islands with the whole of Africa over an extended period of time.

In this way, the main historiographical references would be interested in the island through understanding it, beyond an anecdote, as a universal and strategic territory, although always from the perspective of Western interests (Braudel, 1976: 297). Therefore, within this approach, the islands remained isolated from the main historical processes analysed, unless island processes were of interest to understand major European dynamics. As Rodrigues (2012: 20) points out in the case of Portuguese historiography, it has failed to place the islands within its analytical framework:

Now in histories of Portugal, we forget or place in the background the island territories, such that when "maritime expansion" is discussed the archipelagos of Madeira and the Azores, for example, are not considered.

Even so, we can find some historiographical essays which early on reflected and theorized concerning the implications of the islands in general historical processes. As a result of this debate, both Iberian and Anglo-Saxon historiography began to integrate within their discourses those approaches and research works that had been undertaken at an island level but which, until then, had not had an impact on national research. In this regard we can point out the contributions of Luis de Albuquerque or Vitorino Magalhães Godinho for Portuguese historiography. The former clearly defined that the 
Portuguese Empire was an "amphibious Empire" (Vieira, 2010: 18), consisting of a mainland and an island part, two worlds but only one entity.

The Braudelin-inspired dialectic around the concept of "Amphibious Empire" is very similar to the one already presented by Santana Pérez and Santana Pérez. In the case at hand, Albuquerque indicates the example of islands such as Cape Verde, which are tied to coastal settlements that radiate towards the inland continent, as is the case on Guinea's rivers and coast.

Godinho (1989: 1389), on the other hand, was already at the end of the 1980s urging for island history to be incorporated within a general history. The histories of the islands, in his opinion, should not be confined to the local anecdotal level since they could be of help in understanding more complex and general patterns and behaviour, from the microscopic approach but also as cogs between larger areas,

(...) in the sense of integrating this specific problem of island historiographies within the more general problem of the current orientation of historical research. Because the research carried out in the archipelagos, or concerning the archipelagos, cannot be confined to them.

These reflections, articulated in the twentieth century on the agency of the Macaronesic islands in the historical construction of the Atlantic world, rely on the Braudelian determinism and the dependence of the islands on their surroundings. Nevertheless, a process of rethinking the historical dynamics of the island spaces of Macaronesia has recently begun, but now from the islands outwards.

José Damião Rodrigues argues for the communion between the islands and the spaces which surround them and, accordingly, his analysis also leads to making them part of such general processes. That is to say (Rodrigues, 2012: 21):

no island is isolated, it is always part of a much larger whole and, in this context, also part of "global" history, with use of the "local" perhaps showing itself to be enlightening.

The restless desire to understand the role of the islanders radiating from the islands towards their oceanic background is reflected in Le Canarien, the first chronicle of European dwellers who settle on the islands of Macaronesia which recounts the Norman occupation of some of the Canary Islands during the first quarter of the fifteenth century. Within the account of these chronicles, the geographical description of the island territory occupies a prominent place, but also that of its marine environment in order to solve the enigma of the genesis of the islands anchored inside a vast ocean only recently explored. Island chroniclers such as Gaspar Frutuoso, Alonso de Espinosa, Leonardo Torriani or Abreu Galindo reflected on the "atlanticity" of the Islands. Notwithstanding, it will be the illustrator Viera y Clavijo the first defender of what we might call "atlantonationalism" (Martínez Hernández, 2010: 150). In History, prior to his historical account one finds a dissertation on inserted and well positioned islands in the Atlantic Ocean already dominated by multiple European powers. These island territories, which were believed to be distant, become their discourse in the geographical and geostrategic center of European nations in the Ocean (Viera y Clavijo, 1950: 3):

From the bosom of the Atlantic Sea and in the midst of those happy Islands that serve as the first meridian and as a bridge to the communication of the two worlds subjected to the glorious Empire of the best of Kings.

Paradoxically, despite the collection and selection of accounts originating from common knowledge and tradition by these chroniclers so as to understand the oceanic environment that surrounds the islands, one would have to wait until 
the second half of the twentieth century for the historian Rumeu de Armas to apply the concept of "atlanticity". This author (Rumeu de Armas, 1958: 622) would state, in this sense, and evoking the feeling of Viera, that:

The Canary Islands are, because of their geographical position, the true "finis terre" of the Ancient World and the "finis terre" of the New Continent. Spain and America shake hands in the mythical Fortunate Isles.

\section{The nesology applied to the studies of the historical societies of the Macaronesia region}

Although some historians, such as those cited above, had been worrying about incorporating the evolution of the islands into a general history, we should note that historical science has only just begun to consider the islands as a dynamic and relational element and, therefore, subject to being analysed and contextualised. Although nesological studies have been incorporated as a field of study in other disciplines such as anthropology and philology, historical works which allude to the interpretation of the islands as an element of analysis have been quite scarce. It is worth highlighting the efforts and contributions in the Portuguese field of the aforementioned José Damião Rodrigues, Alberto Vieira and António Correia e Silva, while in the Spanish field, especially regarding the Canary Islands, nesology as a historiographic subdiscipline has no precedents except for some tangential references in the works by Fajardo Spínola and Santana Pérez. In the case of Fajardo Spínola (2009), in his work on migratory movements to the Canary Islands during the Former Regime, he introduced some defining guidelines as to what an island is and what are the characteristics which define it with respect to mainland spaces. For his part, Santana Pérez (2012) proposed a succinct definition of nesology. Likewise, for this historian, the main problem that island studies have suffered in the Canary Islands is that they have been carried out from a local perspective, with no attempt at forming part of broader processes and, even less so, compared or contrasted with other areas.

It is possible at this point to respond to what nesology is and to define what are its analytical tools and its contributions to historical science. As was noted earlier, the concern for island spaces and their perceptibility within the global context derived from the new world order which emerged in the second half of the 20th century and, above all, with the establishing of the UN. The different countries which were incorporated within this international organisation included island nations. With their incorporation, small islands such as those in the Caribbean or Polynesia began to be visible in the eyes of other nations. They started to achieve a certain level of importance through having a voice and a vote and the ability to be involved in decisions beyond the island space. Along with this geopolitical process of being recognised, there was another economic and social component which favoured the recognition of the islands by mainland countries which should be added. Undoubtedly, the development of air transport linked to tourism has helped many "paradisiacal" islands to be visited by millions of foreigners.

However, interest in the islands as a subject of independent and isolated study must be taken back to the mid-19th century with the aforementioned expeditions to remote islands and the evolutionary theories proposed by Darwin, in which the island spaces were awarded special importance. Indeed, the initial concern to studying islands stemmed from the natural sciences and geography. It was not until the 1920s that the island element was incorporated into the social sciences, initially by anthropology and ethnography. These first social researchers - Radcliffe-Brown (1922), Malinowski (1922) and Firth (1940) - focused their studies on the analysis of the islanders as a social component rather than the environment in which they acted (Diegues, 1998: 51). The interest of these first island scholars - not without a certain 
geographical determinism - was probably to analyse an object of study within a well-defined space that would help to understand wider processes.

In the Macaronesic field, the researcher Alberto Vieira (2010:19) was the first contemporary theorist to apply what he called "the new science" to insular historical studies. The historian justly appeals to the need to analyze the past of the Macaronesian islands from the insular studies perspective and advocates encompassing the study of the past of islanders in the concept of nesology and not nysology. The debate on what is the appropriate term to be used has been inevitable, the latter being the form of expression which substantiates acts. He proclaims that the most appropriate term is that of nesology based in turn on the definition established by the Canary philologist Martínez Hernández from the term "nesos" (island) in classical Greek. As of then, other historians of the Macaronesic insular field, such as Juan Manuel Santana Pérez, have continued to use this historical term to construct their accounts from the islands.

The historical nesology proclaimed by Vieira takes as its underlying principle McCall's (1996) proposal that: "the study of islands on their own terms (...) dwellers that island world view is not theirs; and that island integrity belongs to Islanders" and whose definition, has taken shape with the contributions of other researchers like Baldacchino (2008), who emphasizes that these studies have priviledged commentary from inside out y Depraetere (2008), who argues that insular studies are inter and multidisciplinary but also multidimensional.

In this sense, Santana Pérez has defined insular studies as a discipline that requires methodological pluralism within the field of human sciences, from anthropology, sociology, psychology or history; also bypassing literature and the arts. In the words of this historian (2012: 115):

There are many theories about islands as islands, especially epistemological, but closer to literary, philosophical, psychological or economic theories, to the point where we could say that "an island is a portion of land surrounded by theories on all sides". A new branch of knowledge has even been proposed: nesology, a science of the islands that would deal with everything related to them from any point of view.

It is precisely this terminology employed from a historical perspective in the Macaronesic region that has been applied in this research: a historical reconstruction of the perception of the islanders themselves of a historical and mythical past symbolizing an island and maritime culture.

Without a doubt, to understand nesology and island studies, we must study the work of the Brazilian sociologist Antonio Diegues in more depth. For this researcher, the analysis of the relationship between humans, the seas and the islands in their symbolic, mythical and imaginary environments is that which corresponds to nesology (Diegues, 1998: 6). Nesology is concerned with the island from the moment there is interest in knowing its own awareness from within its core, from the actual awareness of the islanders. Thus, the bringing together of the subject [the islander] with the space [the island] constitutes the "island world" which nesological studies seek to understand and define. However, this "island world" is a polysemic construction, with multiple meanings according to the period and the societies analysed; even more important, according to who is visualising it.

The history we analyze here shows that the islands were essential to the future of the islanders themselves as well as the continentals. They were and would be important in the socio-economic field but also in the cultural sphere, as spaces which safeguard memory while spreading knowledge to the ocean shores. We argue, as Alberto Vieira proposed (2010:21), that nesological studies are the universal expression of this "island world". It is, in its essence, a 
World in miniature, a primordial spiritual centre, a complete and perfect image of the cosmos, hell and paradise, freedom and prison, a refuge and the maternal womb, which are some of the meaning's humans have attributed to this microcosm. (Diegues, 1998: 1)

As we can see, the definition proposed by Diegues for the island cosmos is not determined by exogenous approaches which link the islands to isolation, remoteness or as a border; nor even with the fact of being surrounded by water everywhere. The sea, it is true, is an important factor but it is not necessarily a condition which limits the islander. The maritime space is important in terms of the practices that the islanders develop in their relationship with the sea (Diegues, 1998: 259).

In short, nesology aims to understand the construction of consciousness from a particular way of life, different from that of mainland populations. A vision associated with a set of representations and images to which the islanders have given shape in relation to the space - both geographical and cultural - which generates their own insularity. These processes of self-assertion through staging, especially through the recurrent use of myths, are called ileité (islandness) by French geographers and anthropologists, in opposition to the concept of "insularity" which is characterised by the strong component in its meaning of elements such as distance or geographic and social isolation denoted by that term (Diegues, 1998: 3). The term îleité (islandness) responds, therefore, to the life experience of the islanders marked by the very nature of the island space.

For Diegues (1998: 53), many researchers in various fields have based their island studies on the use of exclusively geographical variables; physical constraints such as isolation from other land points or the presence of the sea as an obstacle to communications with the mainland. This processing, based on geographical determinism, has led to the social sciences not being too concerned about investigating concepts such as insularity or islandness as well as defining the "island world" beyond its geographical framework.

However, other researchers, such as the historian Correia e Silva, who analyzes the historical evolution of the Cape Verde and Macaronesia islands, have pointed to geographical constraints as a representative and identity-forming component of island societies. The environment as a defining element would not be given by the exogenous conditions of the island - such as distance or connections with other territories - but by the use made by the islanders of the place itself. That is, it is pointed out as a geographical element conditioning social ecology. In this way, natural conditions will determine the distribution and use of the territory (Correia e Silva 1991: 179):

We start to hypothesize that the actual natural characteristics of the original area will be factors acting, in varying degrees of determinism, to explain the unequal distribution of economic activities in the archipelago territory. If the economy acts by marking the natural territory, introducing new instruments of production, labour force, "works" and "improvements", the opposite is also true. The territory, with its characteristics (soil, winds and rain system, orography, relative location, extension, etc.), within a certain technical framework, imposes what can be undertaken from a range of existing economic activities and excludes others. That is what we call "inverse determination".

He gives the example of the Cape Verde archipelago after the Portuguese colonization process in the 15th and 16th centuries. The economic use made by the first inhabitants of this period was constrained by intra-insular geographical particularities. In this regard, two major geoeconomic areas can be distinguished. One of them covers the islands of Oriente, Norte and Brava. In this area there is extensive livestock farming, mainly exemplified by the goat population. The other region includes the islands of Santiago and Fogo, where agriculture and intensive livestock farming predominate, intricately linked to external markets. This distribution of economic activities is not arbitrary. It does not respond to 
chance or to the result of the free choice of locations by the settlers. There are natural factors which can cause and, in the extreme, absolutely determine this (Correia e Silva, 1991: 179).

However, beyond the geographical determinism to which the islands are subjected, especially throughout the process of human occupation, what is of interest here is highlighting the characteristics which define the island phenomenon. To do this, Diegues proposes a categorization based on three elements already mentioned: the "maritimeness", the "insularity" and the "islander". These terms, together with that of "hypo-insularity", were taken up and claimed as inspiration for the study and debate over the methodology applied in the reconstruction of the history of Macaronesia by Alberto Vieira (2010: 21).

In accordance with this frame of reference, an explanation has been provided for how the presence of the sea is a basic element for island societies. Not so much as the geographical limit forming a border area, but because of the social and symbolic practices of the people in relation to the sea. Maritimeness plays a fundamental role in the representation of the islanders themselves and as a means of relating to exogenous societies. The specificities of the economic, social and symbolic practices of the island population are based on the spatial limitations and the restriction of resources that the maritime space imposes on both the islanders and the foreigners who approach it.

This oceanic environment characterizes the islands and, therefore, the surrounding maritime universe determines the way of life of the islanders. The sea is the nexus, but it is also the abyss that separates them from the rest of humanity. The chroniclers of Macaronesia during the time of consolidation of Atlantic relations, aware of this subordination to the environment, justified this dual bonding by the mythical origin of the islands themselves. In this regard, the chronicler Torriani stated on the Canary Islands at the end of the sixteenth century that "these are the true Fortunate ones, we have many authorities" (Torriani, 1950: 22). To demonstrate this fabulous origin of the insula and the island, he uses in his speech the classic stories, which he adapts and conforms to the environment he is describing. That is, he uses classical tradition to understand his own worldview of the maritime environment around him. In this sense, Torriani (1950:89) infers that:

To Neptune, according to Plato, belonged the Atlantic Island, that is to say, I believe, Africa, as it is almost an island, isolated by the Red Sea; and from it the other islands were called Atlantis, comprising among them the Canary one, whence the other Canary Islands took its name.

Viera y Clavijo (1950:41), the aforementioned islander, erudite of the Enlightenment and historian of the islands of Macaronesia, could not part neither from the imaginary nor the insulo-oceanic worldview and, despite having a literate and learned discourse, atributes with a certain logic and reasoning the origin of the Macaronesian islands to Atlantis itself:

That the Canary Islands and those of the Azores of the Atlantic Ocean, for what they show, are not but summits of very high mountains, it is extremely plausible that they were the strongest and most eminent parts of the Atlantic land; whereby the humblest hills, valleys and intermediate planes were swallowed by some earthquakes and floods, leaving the battlefield by the waters of the sea.

In this sense, island societies are subject to a dual maritimeness. In terms of their relationship with the sea as the cause of their geographical isolation, as well as an element linking the outside world. But the islanders are also dependent on this environment in terms of the economic, social and cultural activities bestowed by the sea. 
The perception of distances and times varies since periods and terms are imposed by maritime conditions. The sea and maritimeness, unlike in continental spaces, indisputably determine the future and success of island societies. These island chroniclers dwell on the nuances that condition insularity and which can only be perceived by islanders (Galindo, 1848: 227):

Having discovered an islet that is a little more than three leagues away from the island of Madera which they call Puerto Santo was discovered nineteen years before the island of Madeira was discovered, when fishermen went fishing along it. And then, once the island of Madeira was discovered, time passed until the desert island was discovered, which is seven leagues away.

Insularity, on the other hand, is understood as the set of practices resulting from human interaction with a marginal area differentiated from the mainland, namely the maritime area. Therefore, the relationship with these limes which we call maritime will be explored and interpreted by island societies. However, as Baldachino points out (2008:45) in his "The First Dilemma", the "cultures of loyalty" persist. Fajardo Spínola (2009:175) reflected on this disjunction of historical island societies and concluded that: "not all islands are open to the sea, but some have had their backs to it. On the contrary, insularity should not be confused with isolation". In the same sense, Professor Godinho (1989: 1391) also points out that insularity is an inherent characteristic in the islands but granting this term excessive privilege would result in a simplistic conceptualization of it. It is a complex idea full of nuances and notions. In this sense, he points out that if this concept focuses on the problems of an island's isolation, this process should be compared with other equally isolated mainland areas, "for example, on the mainland itself, even villages a short distance from Lisbon have nothing to do with the capital".

For its part, the concept of insularity marks the economic and social practices arising from the daily life of a geographically fragmented and limited territory. Insularity forms a physical frontier but also differs in the cultural and symbolic aspects stemming from the mainland since the islands are separated by the sea keeping them independent.

Finally, we have already referred to the term islandism, which constitutes the symbolic representation of the island in relation to its insularity and its bond with the maritime environment which surrounds it.

Thus emerges the popular belief of the existence of the imaginary island of St. Brendan and that the chroniclers identify as one more of the Macaronesia. With immense detail authors such as Torriani $(1950,253)$ capture the experience of Portuguese navigators who arrive at this island and, with whose descriptions, build a mapping of it:

(In the) year 1525 came to this island some Portuguese sailors, coming from Lisbon to La Palma. They landed on it, to plight their ship, which had too much water; and mentioned that it was crossed by a river, and was full of very large and very thick trees; and sited it 220 miles away from La Palma.

These general concepts proposed by the Brazilian sociologist to understand island territories, in terms of the relationship of their inhabitants with the environment and the construction of a cosmos identifying the community must be applied to specific territories which must also be defined. We take up Baldacchino's explanations and, more specifically, Fajardo Spínola's as to the historical field, in order to understand different parameters when it comes to materializing an island. The continental or precontinental islands are not the same as the oceanic islands and, in the case analysed here, consideration has to be given to those which are located within major navigation routes and those separated from them.

If we focus on the case of Macaronesia, these islands form a reality of their own characterized by the following elements: 
- The Azores, Madeira, the Canary Islands and Cape Verde are spaces made up of two or more islands which give rise to as many archipelagos.

- In turn, the set of these archipelagos gives shape to a larger unit that we can call the "Macaronesian island region" in which there are 42 island spaces among islands and islets, of which 28 are inhabited. In addition, the surface of each of these spaces is uneven, ranging from the $0.015 \mathrm{~km}^{2}$ of Roque del Oeste to the $2,034.38 \mathrm{~km}^{2}$ of the island of Tenerife, both in the Canary Islands. Likewise, all of them occupy a total area which is greater than $14,500 \mathrm{~km}^{2}$.

- The fragmentation and dispersion of these spaces means that there is a distance of almost $3,000 \mathrm{~km}$ between the farthest points, the island of Corvo in the Azores and Brava in Cape Verde. Likewise, these are spaces conditioned by their context in relation to the continents. While the Azores is about 1,400 km from Lisbon, the Canary Islands are located less than $100 \mathrm{~km}$ from the African coast and, in contrast, about $940 \mathrm{~km}$ from Cabo de San Vicente as the closest point in relation to Europe.

- They share a volcanic origin, which historically has restricted their inhabitants due to the lack of metallurgical resources that would allow the own manufacture of tools and, consequently, the need to import metals or manufactured products.

- Despite the remoteness of the archipelagos, especially with respect to Europe and America, the trade winds and sea currents which pass by the islands have enabled fluid contacts with the surrounding spaces. However, not all the archipelagos have been favoured by these circuits. While the Canary Islands were the gateway to the New World and the Azores was a forced stopover on the return journey of ships from America to Europe, Madeira did not form part of this maritime and commercial movement.

- This distance from Europe and, therefore, from the organs of power - especially from the metropolis - will have an impact on the island organization itself and its relationship with the surrounding areas, building a linear and direct discourse on the part of the islanders towards the European mainland as the centre of administrative power in which its peripheral situation and the repercussions of this area is continually reinforced, both for the islands and the metropolis.

- This discourse of peripheral areas and, therefore, that of being remote, can be contrasted with the closeness and intense contacts with certain surrounding areas.

- This is a set of intra-Atlantic spaces which, in the words of García Ramos (2002), form part of the Atlantic Cultural Region. That is, for the Macaronesian islands islander, the Atlantic space is a determining variable for the construction of the island's cosmos, the Atlantic being a symbolic element of its identity.

In short, in contrast to the particular aspects which underline fragmentation and remoteness, complementarity is the backbone of these archipelagos, which unites, connects and dynamizes each of these islands with regard to the others.

\section{The complementary system: The essence in the maritime culture of the Macaronesian society}

The Madeiran historian Alberto Vieira, in his numerous works on relations and interconnections between archipelagoes demonstrated the principle of complementarity between island spaces of Macaronesia. The peripheral situation of the Islands, the fragmentation of the island space and, above all, the relationship of each of these microuniverses with the outside required the consolidation of bonds of solidarity to ensure sustenance through the transfer of commodities, the exchange of exogenous manufactures to the islands and the movement of people between archipelagoes. 
However, unlike Godinho, his approach states that the interaction of the islands with the surrounding environment, through maritimeness, is not limited to contacts with the Atlantic territories. Along with these great commercial routes, the way of life of the island is supported by cohesion and bonds between the islands, providing resources and alleviating needs between certain areas and others. The strength of these intra-island ties is what provides value to the islands within a greater hierarchical context. In 1987, as an initial approach, still with a certain Braudelian influence, he announced the principle of complementarity between areas (Vieira, 1987: 15):

The closeness and neighbourliness of the islands which make up the "Mediterranean Atlantic" will be jointly responsible for this identity, as well as the asymmetries and complementarities of their economic development. These dominant characteristics of the island world are the only stabilizing mechanisms for island socio-economic conditions, since they have created the necessary conditions to solve daily problems and enhance local potential. Certainly, the only possibility for the island economy will be to assert itself given the pressure and dominance of Western Europe.

Vieira carried out an unusual analysis of the common fate of these islands based on this complementarity. Thus, he prioritized the bonds between islands, creating an internal and own history, vis-à-vis the until then exogenous historical perspective that prevailed in the insular analysis in relation to ties with the sovereign European nation. From this intrinsic study of the island world he built a nesological history but overturned to the ocean (Vieira 2006: 5):

Historiography has shown that the external relationship of the islands cannot be summarized as just their inter-oceanic and inter-continental relations. On the edge of these important routes and markets there were others which have activated the island economy since the 15th Century. The connections between the nearby (the Azores and the Canaries) or distant archipelagos (Cape Verde, São Tomé and Príncipe) were the reason for the detailed explanation which revealed the role which fostered the improvement of the commercial structure of the islands.

These ties between island societies went beyond trade flows. Mobility between the different Macaronesic archipelagos favored the construction of a common cultural and religious imaginary. Alonso de Espinosa $(1967 ; 80)$, at the end of the sixteenth century, collects in his description of the islands several stories that link Portuguese island individuals with the devotion to the image of the virgin of Candelaria, typical of the Canary Islands:

In a few days, came from the islands below to this one certain Portuguese, they knew the said image (of Candelaria) and claimed to have seen it on the island of Fuego, and that shortly before that island was burned, this image disappeared from there.

The complementarity as an expressive process of linking between island areas responds to a historical and, therefore, changing phenomenon. This fluid communication between islands is triggered by a specific part of the island society, a specific group with the capacity to undertake such actions through the means and resources available to them. Therefore, they will act in their own interest to the detriment of the community good, which opens the door to being vulnerable and more dependent on the outside. That is, this complementarity (Fajardo Spínola, 2009: p. 176):

is not necessarily exercised for the benefit of all members of the island community, but rather for its guiding members, which also affects population movements. It can become a competitive model when there is the same offer, of an exported product or at the services level. That is why island societies can also be especially vulnerable if there is excessive specialization, a strong dependence or a situation involving a lack of communication.

What converges in the islands, as a fruit of maritimeness, is the complementarity between the island areas providing support for the maintenance of the main mercantile routes, acting as strategic enclaves (Vieira, 2006). In this regard, the 
islands of Macaronesia formed an essential terrain to feed and boost transatlantic circulation. For example, for the Modern Age, the island of Santiago was, in this context, a storage point for African goods (slaves, wax, ivory, etc.) waiting to be re-exported to other destinations (Portugal, Castile, Madeira, the Canary Islands, Flanders, etc.), or conversely, a place to temporarily store products of European origin (cloths, horses, jewellery, etc.), to be subsequently re-sent to the coast of Guinea (Correia e Silva, 1991: 199).

Therefore, the improvement of an area - in this case the islands - does not depend on its size or geographical location, or even the importance of internal production as a commodity for outside the island which must be qualified. The attraction of certain islands, such as those in the Macaronesian region, is their ability to cross distant paths, redistribute products and promote migratory flows. As Correia e Silva points out, the islands themselves do not generate any contribution as long as they are not connected to other areas. As in a chess game, a pawn can become essential for the king's survival (Correia e Silva, 1995: 2):

Places whose value and importance are contrasted with the reduced physical dimension or the limited endogenous wealth possessed. As in a game of chess, the value of a piece depends less on the possibilities provided to it a priori, by the rules, than a certain momentary configuration present on the chessboard. A mere pawn can thus suddenly become essential to the survival of the king which, so to speak, is vital to the reproduction of any economic-political setup. But in a chessboard, like the geo-economic complex, setups are altered. All stability is precarious. An uninteresting area, barely in demand yesterday, could be converted, almost from one day to the next, into an effervescent centre of convergence to then, years, decades or even centuries later, becoming a place of decadence, gradually losing, in an accelerated manner, the economic, political or cultural vitality that it has intensely hosted.

The islands become strategic enclaves, places for the entry and exit of people and products. They are dynamic spaces that act as doors between certain areas and others. They are places of transit, the border for which is the permeable sea. For the islanders, an energetic and related connection with the outside through the ports and the beaches. This narrow strip of coastline connects the indomitable universe, the immense ocean, with the inland order and civilization. As Diegues (1998: 182), points out,

the beaches also signify the danger of invasions, the seas, the detritus of the sea and foetid air. (...) islands with beaches means the non-civilized, or not domesticated, the rule of the wild, as is the case on the beach of Robinson Crusoe's island.

For a historical analysis, in addition, this coastal "limes", this border of the island territory, is the area that acts as a nexus with the outside (Rumeu de Armas, 1958: 622). A place of movement and exchange, but not of production. Port cities are especially dynamic areas where everything changes. They are enclaves that act as intermediaries between the interior, agriculture, and exterior markets. Therefore, the inhabitants of port - such as the port of La Orotava in Tenerife, Funchal in Madeira or Angra in Terceira - do not live from direct production, but from the exchanges of what was produced by foreign products on the island (Vieira, 1992). Hence, these inhabitants are mostly dedicated to trade, both large-scale and retail, as well as other services linked to this commercial flow. Consequently, it is the people, neighbours and nonresident, who carry out this communication between the island world and the exterior. As Herzog (2013: 163) pointed out:"(The) mercantile activities greatly modified the meaning and extension of citizenship". This mutual interest, of the islander for the external supplies and that of the foreigners for controlling part of the products that arrive at this maritime port, will give rise to the formation of a mixed society in these ports in which the exogenous individual will be as important as the native (Hespanha, 2019: 31). 
Those who forge this union between the two worlds, the island and the mainland, are individuals from the sea. An amphibious community which connects ports and societies. These individuals have spent most of their lives at sea, which has endowed them with a different view of the area with which they interact. The behaviour and organizational model of the group of sailors are completely different from other groups. Experiences acquired through contacts with other peoples and continents are infinitely more extensive than the locals, even the urban populations with few chances of travelling. The rules of life on land, the warnings of the local parish priest, the power of local authorities hardly matter to seamen living under collective isolation (Diegues, 1998: 69).

These maritime societies have their own symbolic representation of the territory in which they live. This imaginary is constructed, according to the period, from images or referential symbols, which may be different from those used by mainland societies. Even in the same island society, the native islanders have a different vision of the territory than that created by the outsiders who have settled there - like the Portuguese who arrive in the Canary Islands during the Iberian Union (Álvarez Santos, 2019) - since they migrate at a specific period of their lives and, therefore, with acquired experiences (Diegues, 1998: 7). Not even those born on other islands mix in completely in other island territories since each island is a symbolic universe of its own, constructed from its own references and its own affinity with the environment. Thus, for example, there are island societies - mainly on large islands such as Great Britain, Australia or Japan - whose inhabitants have forgotten or can ignore that they live on an island. But if we apply this principle of the transposition of an insular environment to another as applied to the Atlantic islands - let us think of those from Madeira or the Azores in the Canary Islands - the cultural baggage incorporated by these islanders, although similar, still differs in terms of language, religious practices, etc. However, above all, because it involves an adaptive process which begins by leaving a homogeneous parental community or group to establish themselves as individuals in a different social framework.

\section{The mythical construction of the island culture}

As Guimerá Ravina (2017: 1) pointed out, Viera y Clavijo is:

an outstanding figure of the cultural past of the Canary Islands and pioneer of the modern regional history in Spain. In his historical labour Viera worked on the role of the Atlantic in the historical evolution of the Canaries, from the Antiquity to the 18th century.

The islander identity is indebted to the work of Viera y Clavijo, many of their myths and imaginary tear from his history (Santana Pérez, 2017: 43). Viera y Clavijo (1950: 41), combines the perception of being insular in the Atlantic space with the representation of the island world. Certainly, myth is present in all forms that construct identity, both at the group and individual level. It does not come as a surprise that the fundamental and original form of vital consciousness lies in myths and their explanatory model of reality has governed human thought from the very beginnings. All literature has emerged from myths.

There are quite a few Macaronesian islands historians and philologists who have attempted to reconstruct this imaginary from fabulous interpretations about the remote and legendary past of these crags in the Atlantic. In this sense, María Rosa Alonso -a philologist and specialist in island literature of the early Modern Age, rewrites in 1953 the island's own past from her own island perception, from her own experience (1953: 2): 
The most island of all the islands is the inaccessible one, the island that can never be reached (...) Terra firma has always been a serious, continental, land and not that anguish of pieces, fragments of truth, which are the islands, never delivered, always deceit stalking humans on the high seas.

The island is built from the perception of the insular itself in opposition to the parameters established by science. Distances and times are independent autonomous measurements for these territories. Thus, the story and the origin of the islands have been forged from their own entrails and not vice versa. These, therefore, constitute a sacred space with the myths being its symbolic exemplification. As the author contends: "just like good myths, Saint Brendan's Island has also become our symbol".

In the island imaginary there are some recurring patterns and elements. Complex references such as mother and son associated with the sea and the island. María Rosa Alonso (1953: 2), in the aforementioned text San Borondón a la vista, glimpses femininity, the maternal-filial relationship between water and land: "The island is prey and bewitchment, feminine flavour, offering and escape". The islander arises from the entrails of the sea, as confirmed by another islander of Macaronesia, Vitorino Nemésio (1932:59):

I am glad to have been born by the sea, it seems to me an omen of freedom and exchange. He wrote the truth. And even more so when you are born, better than by the sea, in the very bosom and boundlessness of the sea.

The almost virgin birth in the heart of the ocean is an archetype, a myth which Campbell (1988:21) considers part of the cultural history of humanity, and which the Macaronesian authors have used to emotionally engage the individual with his environment. In this sense, both Vitorino Nemésio and María Rosa Alonso ventured in their literary texts to include McCall's plea and Baldacchino's claim, for whom the islanders are the best guardians of their surroundings (Baldacchino, 2008: 49).

Diegues, as a sociologist, underscores and suggests that the sea represents the island's protective uterus for the islanders. This is verified in numerous legends and myths in which the presence of the sea and the island appear as symbolic elements in the construction of the cosmos and in its cultural genesis (Diegues, 1998: 8).

There are different perceptions of the island universe. The geographical composition itself must correspond to the economic and, above all, social perception. As Rodrigues (2012:34) has already argued, some chroniclers and historians of Modernity - such as Gaspar Frutuoso himself - mention that the Azores archipelago is made up of seven islands and not nine. In the words of the chronicler and collected by the Azorian historian: "on the seven islands of the Azores there is no better plot of land" (Rodrigues 2012: 34). The islands of Flores and Corvo, despite being mentioned, are too far from the Azorian cosmos to be included within the archipelago.

On the contrary, Leonardo Torriani includes Madeira and Porto Santo, like other islands, in the book Descripción e historia del reino de las islas Canarias. These chroniclers do nothing more than insist on the construction of a supra-archipelago or own region linked through constant migratory flows, mercantile interdependence and, ultimately, the complementarity between areas, which would correspond to the configuration of Macaronesia (Viera y Clavijo, 1950: 512).

The islands are an imagined and mythified territory, both for the islanders and for the outsiders. The islands are even territories prone to the construction of fables and mysteries by mainland individuals who have never set foot on them. For the islanders, the island stands as a world in miniature on which a complete and perfect image of the cosmos is reflected. A mythified universe which is founded on an almost sacramental value. In the islands - such as the ones 
analysed here - far removed from various mainland societies, foundational myths are created and reconstructed. This discourse, this own vision inherent to the island area, is used by the islanders - such as those from the Canary Islands during the Former Regime - to address the "other", the kingdom and its metropolis. The essays analysed here are nothing more than an effort to make the distant King understand this construction of the island world projected by its own inhabitants. The continuous missives sent by the government of the island of Tenerife to the Monarch are an attempt by the governing bodies of the island to transmit an island ideal, which is symbolic as well as real for the conscience of the island collective, which repeatedly clashes with perception and myth - and the demands arising from him - assimilated across the sea, on the European mainland.

\section{The identity of contemporary Macaronesian society}

Every individual who has not been born on an island is a foreigner, an intruder. Consequently, the construction of the island identity involves contrast with the other, the non-islander. An isolated island society - like the pre-European Canarian aboriginal - has no awareness of insularity, while contact with the outsider provides the islander with an awareness of their belonging to an island and, therefore, in the development of an island identity. In this way, the fluid contacts between islands of Macaronesia, which are complementary and which, moreover, were dependent during the Iberian Union, promoted between the Castilian and Portuguese islanders not only a feeling of belonging to a supranational Iberian monarchy (Hespanha, 2019: 37), but also a sensitivity of belonging to the same island region formed by a Portuguese and Spanish population of extrapeninsular origin with its nexus being its insularity (Herzog, 2013: 168). The island concept would arise at this historical moment in Macaronesia, as similarly presented by Baldacchino (2008:50) with its divisions in terms of gender, class, race and even of nation or kingdom.

Correia e Silva, in addition, extends the definition of these islands according to the period of the settlement of the people on the islands. Together with the native inhabitants, he distinguishes between "estantes" (non-resident) and "instantes" (transient) according to their temporal relationship with the island territory. The designation "instantes" refers to the part of the population whose link to the territory is extremely precarious and fluid, people who are in the islands in transit to other parts. These are an important part of the foreign population which passes through the islands, people linked to Atlantic movement and who boost an interdependent network of economies. On the contrary, "estante" refers to those individuals who settle on the islands for a limited period, whether predefined or not (Correia e Silva, 1991:234).

The composition of modern Macaronesian society is the result of a constant migration process which has taken place since European occupation (Elliott, 2001: 22). To understand the make-up of this population, it is not enough to list the different immigrant groups which have arrived at the islands, or even to describe the contributions of one group or another. It is necessary, in these permeable and frontier societies, as Fajardo Spínola (2009: 173) establishes in the case of the Canary Islands, to

(...) distinguish, order and rank those contributions, analyse the social, cultural and institutional framework

(...) which immigrants joined, and the way they did so.

In the words of Diegues (1998:97), this society forming on the islands lives in a "particular ecological niche". That is, the island is to the community what the mainland is to society. Islanders cross borders and boundaries that are not perceived by mainlanders, circumstances which have resulted in particular strategies in the search for development such as complementarity between the islands of Macaronesia - and solving indigenous conflicts in these small 
territories. For those who arrive and settle down, it may be the case that the island is that paradisiacal territory or which has that fictional projection of another world which they had imagined. After all, the island - like any home - can become a fragile and unstable place where you have to carry out your daily life.

The transposition of an emigrant from a mainland to an island is a complex phenomenon, although it is part of a homogeneous movement of emigrants. As Godinho (1989: 1390) explains, there is an adaptation process even regarding the landscape itself which ends up being felt in a different manner. Although the tendency to continue with old routines persists, they must be adapted to new situations. As Vieira (2012: 134) points out:

From the 14th century the Peninsular Monarchs were to discover the islands of the Atlantic sand to embark on disputes for their colonisation. Heedless of this, the population, settled, created permanent bonds of family, relations and interaction in the commercial field, thus defining mechanisms, complementarities, which were seldom understood by those who lived and still live on the mainland.

\section{Island society, maritime community}

In the case of the Atlantic islands, the fact that they belonged to peninsular kingdoms caused the island societies to develop differently from subjects in other parts of the Monarchy, with a European culture and way of life, but where the distancing from the mainland - and from the metropolis - caused the islands to produce their own social configuration, linked on the periphery and with determinant geographical characteristics.

"The main history, in fact, frequently passes through the islands; perhaps it would be fairer, perhaps, to say that it uses them" (Braudel, 1976: 203). Places as tiny as the islands, which a century before the arrival of Felipe II on the throne of Portugal had barely been conquered and incorporated into European cartography, ended up "one beautiful morning" one of the nerve centres for exchanges within the Hispanic Monarchy (Correia e Silva, 1995: 1).

This work seeks to integrate the islands into successive sets of analyses, within different historico-geographical dynamics. What is sought, to recall Godinho (1989: 1395), is to carry out a comprehensive history through comparisons, "we have to make a history which follows a path of comparisons, also at different levels and according to different fields". The comparison between island dynamics allows us to address more complex phenomena. As Valladares Ramírez (2012: 57), points out: "the rise of global history has opened the way to study the Hispanic Monarchy from a new perspective based on comparatism, synthesis and globalization".

Thus, Rodrigues shows that the study of island societies - especially the Azorean in relation to other archipelagos allows us to understand the link between Portuguese and Castilian expansion in the Atlantic. Based mainly on the chronicle of the islander Gaspar Frutuoso this introduces local discourse, understood as the island imaginary confronted with a global viewpoint, represented by the Hispanic Monarchy. Frutuouso, like other island chroniclers, combines the perception of the Atlantic space with the representation of the island world. Following the words of Miguel Carvalho quoted by Rodrigues - Frutuoso "denotes a globalizing view of the Atlantic, on the one hand and, on the other hand, a knowledge of the existence of an insular world" (Rodrigues, 2011: 21). Therefore, the historical construction of Macaronesia arises from the dynamism of island societies, projected onto the sea, during the consolidation of the Iberian Atlantic. The social assembly and formation of a maritime culture of these islands or "aquapelago" through aquatic spaces is witnessed (Hayward, 2012: 5). 
The islands, in relation to their circumatlantic environment during the Early Modern Period, must be interpreted in their full complexity and covered from all areas, beyond the embryonic bond with the metropolis and its other appendices in Africa and America. The islands of Macaronesia should also be understood in relation to other areas and agents which are included in the Atlantic, whether they were territories and subjects of the Hispanic Monarchy, or not. Thus, continuing with the statements made by Rodrigues (2011: 21) for the case of the Azores, the projects of Elizabeth I of England are explained as controlling the archipelago, first with the attack of Francis Drake and then with the support of Don Antonio:

Consequently, in the context of the imperial rivalries and the dispute over control of the sea, which extended to the territories outside Europe, the Azores' geostrategic centrality transformed the archipelago into the privileged scenario for military and naval operations.

The archipelagos, as already mentioned, are those historical pawns, the value of which fluctuates depending on the type of relationship and the direct or indirect manner with which they interact with the wide enveloping space. The local - the islands - in the end, constitute another element within the system. That means that any alteration introduced in any of its parts will cause, before or afterwards, adaptive modifications in the rest.

In the case which concerns us, the Atlantic cannot be considered as "a large immense mass of water populated with islands" (Vieira, 2006: 3), since they are associated and indivisible elements within historical tradition. The islands behave as connecting elements, as intermediaries, between the surrounding coastlines of Africa, America and Europe.

As Pietschmann (2002: 15) pointed out:

First it seems important, that both powers had acquired and settled all the Atlantic arquipelagos situated comparatively close to Europe and Africa very early (...). They became important intermediaries in the process of expansion and transatlantic shipping.

Islands have their own singularity, have many specific functions, but at the same time Islands fully take part in the rich process that both built up an Atlantic system, and contributed to the birth of the first globalisation or, rather, of an authentic first World History (Martínez Shaw, 2011: 819).

This is a paradigm shift in the historical analysis of the islands. Most of the works that have been published referring to the Atlantic Islands until very recently - especially in Spanish historiography - have a markedly insular or, if you wish, archipelago character. However, works such as those of Vieira - based on analysis of the island of Madeira, and Rodrigues - with his study of the Azores - have consolidated a proposal for Atlantic History in which the islands are shown as a prominent element forming a link between surrounding spaces which make up a common Atlantic whole.

The structure of the backbone of a dynamic Atlantic passed through the islands. Around the Atlantic space, transnational mercantile networks were formed with its greatest - and most attractive - profit being long-distance trade, in geographical and cultural terms, where island territories acted as a strategic platform providing intermediation between these different worlds. The islanders themselves were able to take advantage of this exchange on island lands. Cheap, and even banal, products in one place, could be exotic and expensive in the other. Exclusiveness was the mother of commercial prosperity (Correia e Silva, 1991: 187). The distance between markets and exclusivity increased profit. The Islands of the Atlantic were part of this trade, as redistributive axes which, through this synergy, supported the reproduction of the internal structure. For example, in the case of Cape Verde, relations with Africa were vital in the operation of the productive units for the islands of Santiago and Fogo, to the extent that through them the fundamental production factor was acquired, which was slave labour (Correia e Silva, 1991: 189). It was these distant products which 
made up the means of payment that in turn financed imports to the islands of basic commodities. Exogenous goods for some islands on the periphery which sought to supply these to reproduce the European model of living. In this way, and following the example of Cape Verde, the export of leather was one of the main sources of financing for food imports wheat, barley, olive oil or wine - from Castile, so necessary for the island community of European origin (Correia e Silva, 1991: 190).

In summary, as regards the nesological perspective applied to the Atlantic islands in the historical analysis of Modernity, three methods of approaching this have been considered. Although they all emphasize the role of the islands as cogs in circumatlantic relations, each of them highlights different elements or functions of the island area.

Diegues, as a sociologist, highlights the sacramental character of territory. The symbolic world which is built around the island determines the relationship with this territory, both for the islanders and their worldview and for mainlanders and the legendary and paradisiacal character which islands have. In the case of islands of Macaronesia we can refer to the classic myth of Atlantis. The island society conditioned by the myth has built a collective consciousness in which the facts of the story, although unusual, have become plausible and, therefore, these legends have been an indisputable part of the knowledge and tradition of the community. This vision of a mythical and remote island world, as Europeans expanded out along the African coast and throughout the ocean, would materialize and be perceived as a nearby space, until the islands became daily and even mundane surroundings.

For his part, Braudel underlines the economic and commercial importance of the islands as staging posts and places for exchange. However, this international projection of the island territory is conditioned by its fragility as a reduced area far away from the dominant European territories and, therefore, is conditioned to being dependent on the exterior.

Finally, Correia e Silva, although understanding a certain determinism with the exterior and relativizing the role of the islands according to the geopolitics at any moment, also considers that islands in the first place are subject to their actual area and their use. In this regard, he indicates as determining factors the ecological environment and their geographical constraints.

\section{"Macaronesia": a plural sociocultural maritime construction}

The interpretation of "Macaronesia" as a plural sociocultural maritime construction is based on the combination of these three proposals. Understanding each of them in relation to the others. While we cannot speak of geographical determinism, the insular space and the oceanic environs will condition the culture and historical memory of the past. In turn, we observe the eight characteristics with which McCall characterizes the islands in its entirety (the border, marine resources, strategic location, terrestrial space, culture, the imaginary about space, social relations and concern for migration movements) which allow reconceptualization through the multiple interpretations of the Macaronesic world. First, we have displayed how these islands during the Early Modern Period were at the mercy of mercantile behaviour which was carried out at considerable distances from the islands, with hardly any ability to intervene in the needs of other markets. Changes in island economic cycles, including the severe crises which plagued these territories, coincided with periods involving the general restructuring of the Atlantic domain, both commercially and politically, by the Iberic powers. Therefore, the islands were subject to the unfolding of the ongoing restructuring of the circumatlantic space. But this feature of dependence is a consequence, not only of their island status - as a synonym for being isolated - but also of their intrinsic situation in the Iberic Atlantic. 
Secondly, the geographical constraints of Macaronesia, as fragmented, reduced and distant spaces, restricted the European model of life which was established in these lands, but did not limit or alter it too much. It only had to adapt itself to these new conditions. Even though the European population which occupied and settled on the islands, would reproduce the basic principles of European behaviour in its economic, social and cultural aspects on a smaller scale, the structuring of a bonding mechanism in an aquapelago based on the complementarity would not only allow for supply, but also for the survival of the islanders, and, ultimately, would shape their own identity.

Thirdly, the origins of the definition of the islander as an individual that emerges from an experience gained in a particular world, based on facts and myths, will be an archetype in restless construction from the island society itself, visible in its own chronicles and historical accounts. The interpretation of the island authors and the symbology they represent allows us to understand different perceptions of the individual himself on the insular and maritime environment, beyond ocean conditioning and colonial determinism.

First and foremost, historical nesology applied to the Macaronesian archipelagos should enable us to understand and reconstruct the vision of the islanders from and with their surroundings: a "study of islands on their own terms" (McCall, 1994: 104). Not only including the geographical and trade environment, but also, as McCall proposes, with the cultural and social environment that conditions the perspective of interpretation of its limited world.

As Rodrigues (2012: 38 ) points out:

different political-administrative, economic and social realities and experiences were therefore mirrored in the co-existence of spatial representations and different entities.

\section{Acknowledgements}

This article had the support of CHAM (NOVA FCSH / UAC), through the strategic project sponsored by FCT (UIDB/04666/2020).

\section{References}

Álvarez Santos, J.L., 2019. Identidad insular y espacio atlántico. Portugal y Tenerife en tiempos de la Unión Ibérica. Catarata, Madrid.

Aznar Vallejo, E., 2007. Del mar soñado al mar hollado. El redescubrimiento del océano. Cuadernos del CEMYR. 15: 175-195.

Babcock, W.H., 1922. Legendary islands of the Atlantic. A study in medieval geography- New York, American Geographical Society.

Baldacchino, G., 2008. Studying Islands: On Whose Terms? Some Epistemological and Methodological Challenges to the Pursuit of Island Studies. Island Studies Journal. 1: 37-56

Braudel, F., 1976. El Mediterráneo y el Mundo Mediterráneo en la época de Felipe II. Fondo de Cultura Económica, Mexico DF.

Campbell, J., 1988. El poder del mito. Emecé Editores, Barcelona.

Correia e Silva, A., 1991. Espaço, ecologia e economia interna, in: Madeira Santos, M.E. \& Albuquerque, L. (Eds.), História geral de Cabo Verde I. Instituto de Investigação Científica Tropical, Lisbon, pp. 179-236.

Correia e Silva, A., 1995. Cabo Verde e a geopolítica do Atlântico, Madeira Santos, in M.E. (Ed.), História geral de Cabo Verde II. Instituto de Investigação Científica Tropical, Lisbon, pp. 1-16. 
Diegues, A.C., 1998. Ilhas e Mares: Simbolismo e Imaginário. Editora Hecitec, São Paulo.

Elliott, J.H., .2001. En búsqueda de la historia atlántica. Cabildo de Gran Canaria, Las Palmas de Gran Canaria.

Espinosa, A., 1967. Historia de Nuestra Señora de Candelaria. Ed. Goya, Santa Cruz de Tenerife.

Fajardo Spínola, F., 2009. Inmigración e integración en Canarias en la Edad Moderna, in Galván Tudela, J.A. (Ed.). Migraciones e integración cultural. Academia Canaria de la Historia, Las Palmas de Gran Canaria, pp. 173-198.

Galindo, A. 1848. Historia de la Conquista de las Siete Islas de Gran Canaria. Ed. Isleña, Santa Cruz de Tenerife.

García Ramos, J.M., 2002. Atlanticidad. Canarias y la comarca cultural atlántica. Altasur ediciones, Santa Cruz de Tenerife.

Godinho, V.M., 1989. As historiografias insulares: presente e futuro, in I Colóquio Internacional de História da Madeira (1986). Centro de Estudos de História do Atlântico, Funchal, pp. 1389-1398.

Guimerá Ravina, A. 2017. El mar en la obra histórica de Viera y Clavijo. Anuario de Estudios Atlánticos. 63: 1-13.

Hayward, P., 2012. Aquapelagos and Aquapelagic Assemblages. Shima: The International Journal of Research into Island Cultures. 6: 1-11.

Herzog, T., 2013. Merchants and Citizens: On the making and Un -making of merchants in early-modern Spain and Spanish America. Journal of european economic history. 42: 137-164.

Hespanha. A.M., 2019. Filhos da Terra: Identidades Mestiças nos Confins da Expansão Portuguesa. Tinta da China, Lisbon.

Lucena Giraldo, M., 2010. La Historia Atlántica y la fundación del Nuevo Mundo. Anuario de Estudios Atlánticos. 56: 39-60.

McCall, G. 1994. Nissology: A proposal for consideration. Journal of The Pacific Society. 163-64: 93-106.

Martínez Hernández, M., 2010. Islas míticas en relación con Canarias. Cuadernos de Filología Clásica. Estudios griegos e indoeuropeos. 20: $139-158$.

Martínez Shaw, C., 2011. La multifuncionalidad de las islas en la primera mundialización. El prestigio de las islas. Anuário do Centro de Estudos de História do Atlântico. 3: 818-835.

Morales Padrón, F., 1970/ 12/ 30. Siete islas para siete dioses. ABC Sevilla. 12.

Nemésio, V., 1932. Açorianidade. Ínsula. 7-8: 59.

Outhwaite, L., 1957. The Atlantic. A History of an Ocean. Coward McCann, New York.

Pietschmann, H., 2002. Introduction: Atlantic History. History between European History and Global History, in Pietschmann, H. (Ed.). Atlantic History. History of the Atlantic System. 1580-1830, Vandenhoeck\&Ruprecht. Göttingen, pp.11-53.

Rodrigues, J.D., 2011. The Flight of the Eagle: an Island Tribute to the Universal Iberian Monarchy at the End of the Sixteenth Century. E-journal of Portuguese History. 2: 1-34.

Rodrigues, J.D., 2012. Os Açores na primeira modernidade. Centro de História de Além-Mar, Lisbon.

Rosa Alonso, M., 1953. San Borondón a la vista. Gánigo: Poesía y arte. 4: 2-3.

Rumeu de Armas, A., 1958. Crónica: Actividades del Patronato de la Casa de Colón. Anuario de Estudios Atlánticos. 4: 617-645.

Santana Pérez, J.M. 2017. Viera y Clavijo: Historiador ilustrado del Atlántico. História da Historiografia. 23: 43-63.

Santana Pérez, G., Santana Pérez, J.M., 2002. La puerta afortunada: Canarias en las relaciones hispano-africanas de los siglos XVII y XVIII. Catarata, Madrid.

Santana Pérez, J.M., 2012. Islas atlánticas en el comercio entre América y África en el Antiguo Régimen. Cuadernos Americanos. Nueva Época. 142: 113-135. 
Torriani, L., 1950. Descripción e historia del reino de las islas Canarias. Ed. Goya, Santa Cruz de Tenerife.

Valladares Ramírez, R., 2012. No somos tan grandes como imaginábamos. Historia global y Monarquía Hispánica. Espacio, tiempo y forma. Serie IV. Historia moderna. 25: 57-115.

Vieira, A., 1987. O comércio inter-insular nos séculos XV e XVI (Madeira, Canárias e Açores). Centro de Estudos de História do Atlântico, Funchal.

Vieira, A., 1992. Portugal y las islas del Atlántico. Mapfre, Madrid.

Vieira, A., 2006. Madeira y Canarias. Rutas de ida y vuelta. Centro de Estudos de História do Atlântico, Funchal.

Vieira, A., 2010. As ilhas: da Nissologia à Nesologia. Anuário do Centro de Estudos de História do Atlântico. 2: 16-21.

Vieira, A., 2012. Reconstrução e desconstrução do mundo insular do Atlântico Oriental. Séculos XV e XVI, Anuario de Estudios Atlánticos. 58: 133-184.

Viera y Clavijo, J., 1950. Noticias de la Historia General de las Islas Canarias. Ed. Goya, Santa Cruz de Tenerife. 